\title{
Australian attitudes to intergenerational equity: impacts of social and policy change
}

\author{
Hal Kendig ${ }^{1,2}$, Rafat Hussain ${ }^{1,2,3 *}$, Kate O’Loughlin ${ }^{1,4}$ and Lisa Cannon ${ }^{1,2}$ \\ ${ }^{1}$ ARC Centre of Excellence in Population Ageing Research (CEPAR), Sydney, Australia, ${ }^{2}$ Centre for \\ Research on Ageing, Health and Wellbeing (CRAHW), Research School of Population Health, The \\ Australian National University, Canberra, Australia, ${ }^{3}$ The Medical School, Australian National University, \\ Canberra, Australia and ${ }^{4}$ Ageing, Work and Health Research Unit, Faculty of Health Sciences, University of \\ Sydney, Australia \\ *Corresponding author. Email: Rafat.Hussain@anu.edu.au
}

(Accepted 18 May 2018; first published online 16 July 2018)

\begin{abstract}
Attitudes to ageing can predispose decision-making as governments, interest groups and electorates negotiate competing demands in the context of economic constraints and social change. This paper, based on national survey data, investigates change and stability in Australian attitudes to intergenerational equity from 2009-2010 to 2015-2017, alongside concurrent socio-economic and policy change as well as cohort succession. The emphasis is on the baby-boom cohort who are viewed as significant beneficiaries of social change relative to opportunities of younger and older cohorts. Views of older people as a needy group may be changing slightly as more enter later life with substantial wealth and resources. Our results show that there is little perception of intergenerational conflict with the exception of the Millennial cohort whose life chances are compromised by economic and expenditure constraint over the past decade. Overall, attitudes remain sympathetic to older people, especially among women and people rendered vulnerable by poor health, non-home-ownership and low socio-economic positions. The findings do not align with government portrayals of intergenerational inequalities notwithstanding many having negative views of the future and ongoing expenditure restraint strategies. At what appears to be a critical turning point in the life chances of successive cohorts, the findings indicate the interplay between attitudes and social and policy change, as well as implications for social equity and processes of attitudinal change.
\end{abstract}

Keywords: intergenerational equity; baby-boomers; attitudes to ageing; social class; Australia

\section{Introduction}

\section{International context}

Governments throughout the world are challenged by population ageing during times of uncertain economic growth and significant events such as the 1997

(c) Cambridge University Press 2018. This is an Open Access article, distributed under the terms of the Creative Commons Attribution licence (http://creativecommons.org/licenses/by/4.0/), which permits unrestricted re-use, distribution, and reproduction in any medium, provided the original work is properly cited. 
Credit Crisis, the 2007-2009 recession in the United States of America (USA) and subsequent economic slowdown in many developed countries. Major questions are arising as to the sustainability of policies that have traditionally redistributed resources from those in younger and middle ages (relatively recent cohorts) to those in later life (earlier cohorts). The implicit assumption has been that older people are disadvantaged not only by the vulnerabilities and risks of later life, but also by their birth cohort; that is, the relatively reduced opportunities of having lived in earlier periods when standards of living were relatively lower. Over recent years, attitudes sympathetic to the needs of those now in later life have been confronted by increasing indications that the economic and fiscal outlook could be significantly worse for future cohorts (Hurley, Breheny and Tuffin 2017).

Over the post-Second World War era of rising real incomes and expansion of the public sector, the growth of what Binstock (2010) termed an era of 'compassionate' ageing recognised the intense and widespread needs of 'the elderly' and the case for expansion of programmes beneficial for them. The US system of voluntary voting, in which older people made up a disproportionate share of the electorate, reinforced their electoral strength. Walker (1990) presaged later policy debate by suggesting that issues of intergenerational equity, fuelled by the fiscal injunctions of the International Monetary Fund and other international agencies, had been driven largely by ideologies that raised the spectre of population ageing as an economic 'burden' to argue against welfare expenditure. More recently, the political context in the USA has changed along with economic stringencies and more conservative ideologies. In this context, political forces in the USA began to argue for reductions of Social Security and Medicare provisions in order to limit taxation or redistribute benefits to younger people in greater need (Hudson 2016).

In the welfare states in Europe, issues of intergenerational transfers also are heightened as younger people (more recent cohorts) have faced the spectre of modest economic prospects, while the public sector faces the rising costs of growing numbers of older people in an increasingly difficult fiscal climate. Drawing on Kohli's earlier work on intergenerational justice, Kohli and Arza 2011: (260-262) argue for 'political recognition of the full patterns of intergenerational exchange and of the whole life course'. Drawing on the United Kingdom (UK) experience, Higgs and Gilleard (2010) posit that recent cohorts have been entering retirement with more of them maintaining levels of consumption from middle age, with wealth in home-ownership emerging as a major social divide along with income and social class. In New Zealand, universal state-funded superannuation can exacerbate inequalities between generations but ameliorate them within generations by protecting older tenants from poverty (Hurley, Breheny and Tuffin 2017).

\section{Australia and a changing social contract}

Australia over the post-Second World War era has experienced enormous economic growth and considerable policy advances that have been particularly beneficial for the baby-boom cohort now entering later life. Most notable among these developments have been substantial increases in real incomes, rising homeownership levels, and improved provision for income support and health services (Kendig 2017a). Through the 1980s and into the 1990s, a reforming Labor 
government progressively raised the age pension, implemented national superannuation, and improved health and care programmes (Kendig 2017a). In the early 1990s, however, a sharp, short recession led to the return in 1996 of a conservative Coalition government under the rallying cry of 'reigning in Labor's debt'. There is substantial evidence that the advances made by older cohorts in earlier decades are not being achieved by those coming after them and, further, that substantial inequalities persist within the older as well as younger age groups (Daley and Wood 2014; Kendig 2017b).

A new era of avowed austerity was ushered in during the mid-1990s by the first of what eventuated as a series of Intergenerational Reports (IGRs). These reports, authored by Treasurers and Treasuries, made the argument that fiscal caution would need to be exercised with costly social and care programmes that might not be affordable into a future heavily influenced by demographic change (Commonwealth of Australia 2002, 2007, 2010, 2015). The political argument made by the Conservative government in 1996 was that social expenditure on older people (and other disadvantaged groups) would have to be restrained in order to spare future generations from onerous tax burdens and cutbacks on government programmes. The 'intergenerational' theme has been promulgated widely in the media, not only by Conservative political forces but also as an economic and fiscal necessity by powerful Treasuries and Finance departments. This dominant political narrative of fiscal restraint has continued notwithstanding changes of governments that have nonetheless maintained ongoing spending and deficits.

A range of comments on the IGRs have been raised in public policy debates. Commentators sympathetic to the interests of older people have 'named' the political and ideological imperatives behind the IGR reports and the risks of scapegoating older people for the consequence of population ageing (Kendig 2010; Woods and Kendig 2015). They have countered that the narrow fiscal issues could be addressed more constructively through positive actions such as enabling more labour force participation by older people and combatting ageism in the workforce (Australian Human Rights Commission 2015). Duckett (2015) argues that the IGRs have missed the point on health spending and neglected further opportunities for constructive actions. Bessant, Emslie and Watts (2011) observe that the IGRs, with their focus on fiscal sustainability, have paid relatively little attention to fundamental matters of generational and distributive justice.

Australian policy debates on intergenerational equity have had similarities of rhetoric to those in the USA and UK but the policy context is very different, e.g. levels of national debt are far lower. Australia also has a more moderate trajectory of demographic ageing, attributable largely to continuing immigration, and largely uninterrupted economic growth since the 1991 recession. Indeed, the global Credit Crisis of 1997 raised concerns at the time that led to policy action to raise the pension and widen eligibility for those with private incomes and home-owners (Kendig et al. 2013). While older populations in Australia, the USA and other developed countries have comparable levels of income and health profiles (Kendig and Cannon 2016), important Australian differences are (compared to the USA) the less contentious racial, ethnic and social class divides; and (compared to European countries) fewer universal principles in taxation and services. 
This paper investigates Australian population attitudes concerning intergenerational equity at two time-points: the period immediately following the international Credit Crisis (2009-2010) and five to six years later (2015-2017). Using similar questions at both time-points, the research was designed to detect the ways in which attitudes may have responded to the changing socio-economic and policy context outlined above. We report national survey data providing appraisals of the life-long economic prospects of several generations: the Baby-boom Cohort (born 1946-1964) relative to those born before 1946, Generation X (born 19651980 ) and Generation Y (born after 1980). The primary analytical focus is on attitudinal change by each of the birth cohorts which are posited to be sensitive to the particular lifespan transitions that they have been experiencing over this period. For example, the massive baby-boom cohort was moving into the 60+ age group at the time of the surveys and would have been exposed particularly to issues concerning retirement. Conversely, Generation Y, otherwise known as the 'Millennials', were entering adulthood and their life directions were being set by employment markets at the time. In addition to the age/cohort comparisons, we point to social differences in terms of gender, socio-economic resources, urban/rural areas and vulnerability in terms of health.

\section{Methods}

\section{Study design and sample}

The data for the present paper are drawn from the Australian Survey of Social Attitudes (AuSSA), a cross-sectional survey conducted biennially on a nationally represented sample of Australian adults aged 18 years or older; and is Australia's component of the International Social Survey Program (ISSP) (Australian Consortium for Social and Political Research Inc. 2015). The AuSSA contains several modules on various dimensions of social attitudes that are relevant to contemporary societal-level challenges. Earlier rounds of AuSSA also have examined Australian attitudes, e.g. Australian attitudes to inequality and redistribution (Saunders and Wong 2013). The data used for analyses for the present paper were extracted from the module on Attitudes to Ageing in Australia (AAA) designed by our research team and supported by the ARC-funded Centre of Excellence in Population Ageing Research (Kendig et al. 2015). Preliminary baseline findings were presented in Kendig et al. (2017). The module was administered in the 2009-2010 survey $(\mathrm{N}=1,525$; response rate 33\%) and the latest 2015-2017 survey rounds $(\mathrm{N}=2,174$; response rate $27 \%)$. The self-completion, mail-out collection explains why comparisons to the Census reveal some under-enumeration of non-English-speaking migrants and less-educated people in the surveys.

\section{Measures}

A range of socio-demographic questions are asked in AuSSA, ten of which are included in the analyses: age, gender, marital status, location of residence, education, employment status, occupational status, housing tenure, self-rated general health and self-rated societal status. Due to very small numbers of survey 
respondents identifying as Indigenous (i.e. of Aboriginal or Torres Strait Islander descent), no meaningful comparisons could have been drawn and therefore indigeneity was not used as a variable in the current analysis.

\section{Outcome variables}

Each of the two rounds of the AAA component of AuSSA contained several questions on perceptions of ageing ranging from intergenerational opportunities, discrimination in the workplace and other questions on perceptions of ageist attitudes. The first three outcome variables used in this paper were developed for the 2009-2010 survey and replicated in 2016-2017. The fourth on intergenerational conflict was replicated in both surveys from the ISSP Social Inequality Survey (ISSP Research Group 1989).

(1) Life-long opportunities for baby-boomers compared to younger people: 'Each generation has different social and economic opportunities over their lives. How would you say the life-long opportunities for baby-boomers (aged 50 to 64 years [in 2009-2010]) compare to those for younger people today?' (response categories: 'better for baby-boomers'; 'about the same'; 'better for younger people').

(2) Life-long opportunities for baby-boomers compared to those who had already retired: 'How would you say the life-long opportunities for babyboomers (aged 50 to 64 years [in 2009-2010]) compare to those for older people who have already retired?' (response categories: 'better for babyboomers'; 'about the same'; 'better for the already-retired people').

(3) Fair share of government benefits for older people: 'Right now, do you think older people are getting more than their fair share, less than their fair share, or about their fair share of government benefits?' (response categories: 'more than their fair share'; 'less than their fair share'; 'about their fair share'; 'don't know').

(4) Intergenerational conflict: 'In all countries, there are differences or even conflicts between different social groups. In your opinion, in Australia how much conflict is there between older people and younger people?' (response categories: 'strong conflicts'; 'not very strong conflicts'; 'no conflicts'; 'can't choose').

\section{Analyses}

The analyses comprised univariate and bivariate techniques; correlational matrices and multivariable logistic regression using the software SPSS version 24 (IBM Corp 2016). Ten socio-demographic characteristics were included in the current analysis to explore social variation: age, gender, marital status, location, education, employment status, occupational status, housing, self-reported general health and self-rated societal status (see Table 1).

Before undertaking univariate analyses, we categorised and recoded some of the covariates. As per Table 1, age was categorised into four groups: young (born after 1980), middle (born 1965-1980), baby-boomer (born 1946-1964) and older (born before 1946). Marital status was categorised into two categories: ever been married 
and never been married. Education was categorised (based on years of formal schooling) into three categories: up to Year 12, technical and further (vocational) education (TAFE), and tertiary or higher education. Occupation, originally listed in categories as per standard definitions used by the Australian Bureau of Statistics, was compressed into three more manageable categories of managerial and professional, trades and clerical, and machinery operators and labourers. The variable 'self-rated societal status', originally applied in the 1987 ISSP survey, provided a basis for equivalency across people who were employed and those who were not in the labour force. It used a ten-point Likert ranking scale (1-10), with 1 being the lowest and 10 the highest. It was recoded into three broad categories of bottom (1-4), middle (5-7) and top (8-10).

To assess change across the two survey periods, a range of dummy variables were created, and statistical significance was tested using $t$-tests. To examine the variation in perceptions, outcome measures were recoded as dichotomous variables using a consensus-based approach of examining contrasting perceptions and opinions. For each of the four outcomes, the dichotomous variables were selected based on contrasts in opinions with more than 5 per cent change over time, and were as follows: (a) 'better for baby-boomers' and 'better for younger people'; (b) 'better for babyboomers' and 'better for already-retired people'; (c) 'about fair share' and 'less than their fair share'; (d) 'no conflict' and 'strong conflict'. Only variables with values of less than 0.6 on a correlational analysis were included in the regression models. The logistic regression findings reported in the text were significant at $p<0.05$. However, some statistically significant results were not included due to small cell sizes as this produces unstable estimates of odds ratios with very wide 95 per cent confidence intervals (CI) (Büttner and Muller 2011).

\section{Results}

\section{Sample characteristics}

The sample characteristics are summarised in Table 1 . There were some differences in age and gender profile with a predominance of baby-boomers and older people in both survey rounds; and slightly more female respondents (57\%) in the 20092010 survey, but no appreciable gender difference in 2015-2017. Approximately 75 per cent of respondents at both time periods were born in Australia (data not shown). Consistent with the residential pattern of the Australian population, the majority of survey respondents were in metropolitan areas. There were only minor occupational, employment and educational differences across the two survey periods, with a higher proportion of respondents having a tertiary education in the latest round compared to 2009-2010. Similarly, there were only small differences regarding housing tenure, with two-thirds of respondents being outright homeowners or purchasers at both times (see Table 1). The variable where major change was noticeable across the two survey periods was self-rated general health. In 20092010, about 28 per cent of respondents reported their health to be fair/poor compared to only 18 per cent in 2015-2017. Lastly, across both survey periods an important question in the AuSSA survey measured individuals' self-rated societal status. At both survey periods almost two-thirds of the respondents ranked 
Table 1. Sample characteristics in 2009-2010 and 2015-2017

\begin{tabular}{|c|c|c|c|c|}
\hline \multirow[b]{2}{*}{ Characteristics } & \multicolumn{2}{|c|}{$2009-2010$} & \multicolumn{2}{|c|}{$2015-2017$} \\
\hline & $\%$ & $\mathrm{~N}$ & $\%$ & $\mathrm{~N}$ \\
\hline \multicolumn{5}{|l|}{ Age cohort: } \\
\hline Young (born after 1980) & 10 & 155 & 13 & 268 \\
\hline Middle (born 1965-1980) & 19 & 311 & 21 & 471 \\
\hline Baby-boomers (born 1946-1964) & 31 & 616 & 38 & 967 \\
\hline Older (born before 1946) & 39 & 402 & 28 & 343 \\
\hline \multicolumn{5}{|l|}{ Gender: } \\
\hline Male & 43 & 647 & 49 & 1,029 \\
\hline Female & 57 & 847 & 51 & 1,067 \\
\hline \multicolumn{5}{|l|}{ Marital status: } \\
\hline Ever been married & 78 & 1,166 & 81 & 1,669 \\
\hline Never been married & 22 & 325 & 19 & 391 \\
\hline \multicolumn{5}{|l|}{ Location: } \\
\hline Metropolitan & 62 & 921 & 60 & 1,240 \\
\hline Region & 12 & 176 & 25 & 515 \\
\hline Rural & 26 & 390 & 15 & 320 \\
\hline \multicolumn{5}{|l|}{ Education: } \\
\hline Up to Year 12 & 30 & 447 & 29 & 608 \\
\hline Diploma/TAFE & 41 & 610 & 35 & 727 \\
\hline Tertiary education & 28 & 420 & 37 & 769 \\
\hline \multicolumn{5}{|l|}{ Employment status: } \\
\hline Employed & 53 & 785 & 59 & 1,217 \\
\hline Unemployed & 2 & 23 & 4 & 77 \\
\hline Retired & 23 & 336 & 27 & 560 \\
\hline Household duties & 12 & 171 & 4 & 82 \\
\hline Other & 12 & 173 & 6 & 115 \\
\hline \multicolumn{5}{|l|}{ Occupational status: } \\
\hline Managers and professionals & 41 & 560 & 44 & 848 \\
\hline Trades and clerical workers & 47 & 639 & 46 & 889 \\
\hline Machinery operators and labourers & 13 & 175 & 10 & 189 \\
\hline \multicolumn{5}{|l|}{ Housing: } \\
\hline Own (outright) & 45 & 669 & 44 & 902 \\
\hline Own (mortgage) & 32 & 472 & 33 & 688 \\
\hline Rent & 15 & 222 & 17 & 340 \\
\hline
\end{tabular}


Table 1. (Continued.)

\begin{tabular}{|c|c|c|c|c|}
\hline \multirow[b]{2}{*}{ Characteristics } & \multicolumn{2}{|c|}{$2009-2010$} & \multicolumn{2}{|c|}{$2015-2017$} \\
\hline & $\%$ & $\mathrm{~N}$ & $\%$ & $\mathrm{~N}$ \\
\hline Other & 8 & 123 & 6 & 129 \\
\hline \multicolumn{5}{|l|}{ General health: } \\
\hline Excellent & 18 & 264 & 14 & 170 \\
\hline Very good/good & 54 & 807 & 68 & 798 \\
\hline Fair/poor & 28 & 422 & 18 & 215 \\
\hline \multicolumn{5}{|l|}{ Societal scale: } \\
\hline Top (8-10) & 12 & 183 & 22 & 430 \\
\hline Middle (5-7) & 72 & 1,074 & 66 & 1,301 \\
\hline Bottom (1-4) & 16 & 230 & 12 & 235 \\
\hline Total & 100 & 1,525 & 100 & 2,174 \\
\hline
\end{tabular}

Notes: Percentages that do not add up to 100 are due to rounding error. TAFE: technical and further education.

themselves in the 'middle of society' (72 and 66\%, respectively). More noteworthy is that in 2009-2010 only 12 per cent ranked themselves in the top category of the scale compared to 22 per cent in 2015-2017 (see Table 1). Apart from sampling variation, it is also plausible that such a finding may have been influenced by the people who felt relatively less confident of their financial situation immediately after the international Credit Crisis.

\section{Life-long socio-economic opportunities}

There are two components to this domain which provide a general appraisal of lifelong opportunities: baby-boomers compared to younger people, and baby-boomers compared to older retired people. Overall, more respondents perceived that lifelong opportunities were better for baby-boomers than for either younger or already-retired people (see Figure 1). In 2009-2010, a similar proportion of people thought the opportunities were better for baby-boomers and for younger people (39 and 38\%), while in 2015-2017 there were more people who thought the opportunities were better for baby-boomers (49\%) than for younger people $(27 \%)$. This change over time was greatest amongst the youngest cohort who were the least likely to think baby-boomers had better opportunities in 2009-2010 (34\%) and were the most likely to think so in 2015-2017 (58\%) (see Figure 1; Table 2). At both time periods, very few people thought retired people (13 and 17\%, respectively) had better opportunities than baby-boomers ( 58 and $49 \%$, respectively). Overall, there was a slight decline in the proportion of respondents who thought baby-boomers had it better, with the largest change found amongst the baby-boom cohort itself (from 61 to $46 \%$ ) (see Figure 1; Table 3).

Compared to their respective counterparts at both time periods, a higher portion of people with a tertiary education, and those who were managers and 


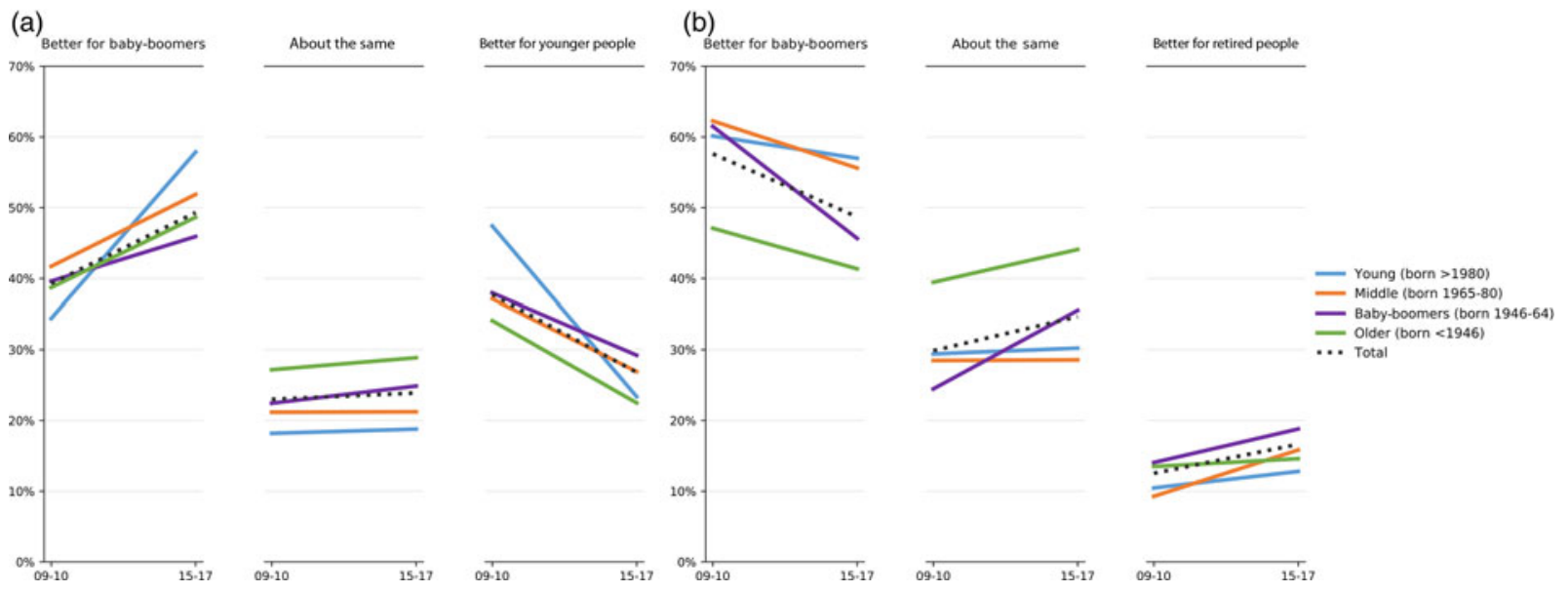

Figure 1. Life-long opportunities of baby-boomers compared to (a) young people or (b) already-retired people. 


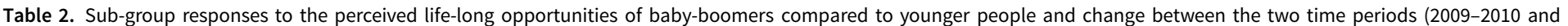
2015-2017)

\begin{tabular}{|c|c|c|c|c|c|c|c|c|c|c|c|}
\hline \multirow[b]{2}{*}{ Characteristics } & \multicolumn{3}{|c|}{ Better for baby-boomers } & \multicolumn{3}{|c|}{ About the same } & \multicolumn{3}{|c|}{ Better for younger people } & \multicolumn{2}{|c|}{ Total N } \\
\hline & $\begin{array}{c}2009-10 \\
(\%)\end{array}$ & $\begin{array}{c}2015-17 \\
(\%)\end{array}$ & $p$ & $\begin{array}{c}2009-10 \\
(\%)\end{array}$ & $\begin{array}{c}2015-17 \\
(\%)\end{array}$ & $p$ & $\begin{array}{c}2009-10 \\
(\%)\end{array}$ & $\begin{array}{c}2015-17 \\
(\%)\end{array}$ & $p$ & $2009-10$ & $2015-17$ \\
\hline \multicolumn{12}{|l|}{ Age cohort } \\
\hline Young (born after 1980) & 34 & 58 & * & 18 & 19 & & 47 & 23 & * & 154 & 261 \\
\hline Middle (born 1965-1980) & 42 & 52 & * & 21 & 21 & & 37 & 27 & * & 307 & 457 \\
\hline Baby-boomers (born 1946-1964) & 40 & 46 & * & 22 & 25 & & 38 & 29 & * & 606 & 941 \\
\hline Older (born before 1946) & 39 & 49 & * & 27 & 29 & & 34 & 22 & * & 390 & 329 \\
\hline \multicolumn{12}{|l|}{ Gender: } \\
\hline Male & 41 & 51 & * & 25 & 25 & & 34 & 25 & * & 636 & 1,005 \\
\hline Female & 38 & 48 & * & 22 & 23 & & 40 & 29 & * & 831 & 1,027 \\
\hline \multicolumn{12}{|l|}{ Marital status: } \\
\hline Ever been married & 40 & 48 & * & 24 & 25 & & 36 & 28 & * & 1146 & 1,617 \\
\hline Never been married & 35 & 56 & * & 22 & 20 & & 43 & 24 & * & 320 & 381 \\
\hline \multicolumn{12}{|l|}{ Location: } \\
\hline Metropolitan & 41 & 52 & * & 22 & 22 & & 37 & 26 & * & 904 & 1,199 \\
\hline Region & 41 & 46 & & 20 & 27 & & 39 & 28 & * & 176 & 504 \\
\hline Rural & 35 & 45 & * & 26 & 26 & & 39 & 29 & * & 381 & 311 \\
\hline \multicolumn{12}{|l|}{ Education: } \\
\hline Up to Year 12 & 34 & 44 & * & 26 & 25 & & 40 & 31 & * & 440 & 584 \\
\hline Diploma/TAFE & 37 & 44 & * & 23 & 26 & & 40 & 30 & * & 596 & 705 \\
\hline Tertiary education & 48 & 58 & * & 20 & 20 & & 32 & 21 & * & 415 & 753 \\
\hline
\end{tabular}




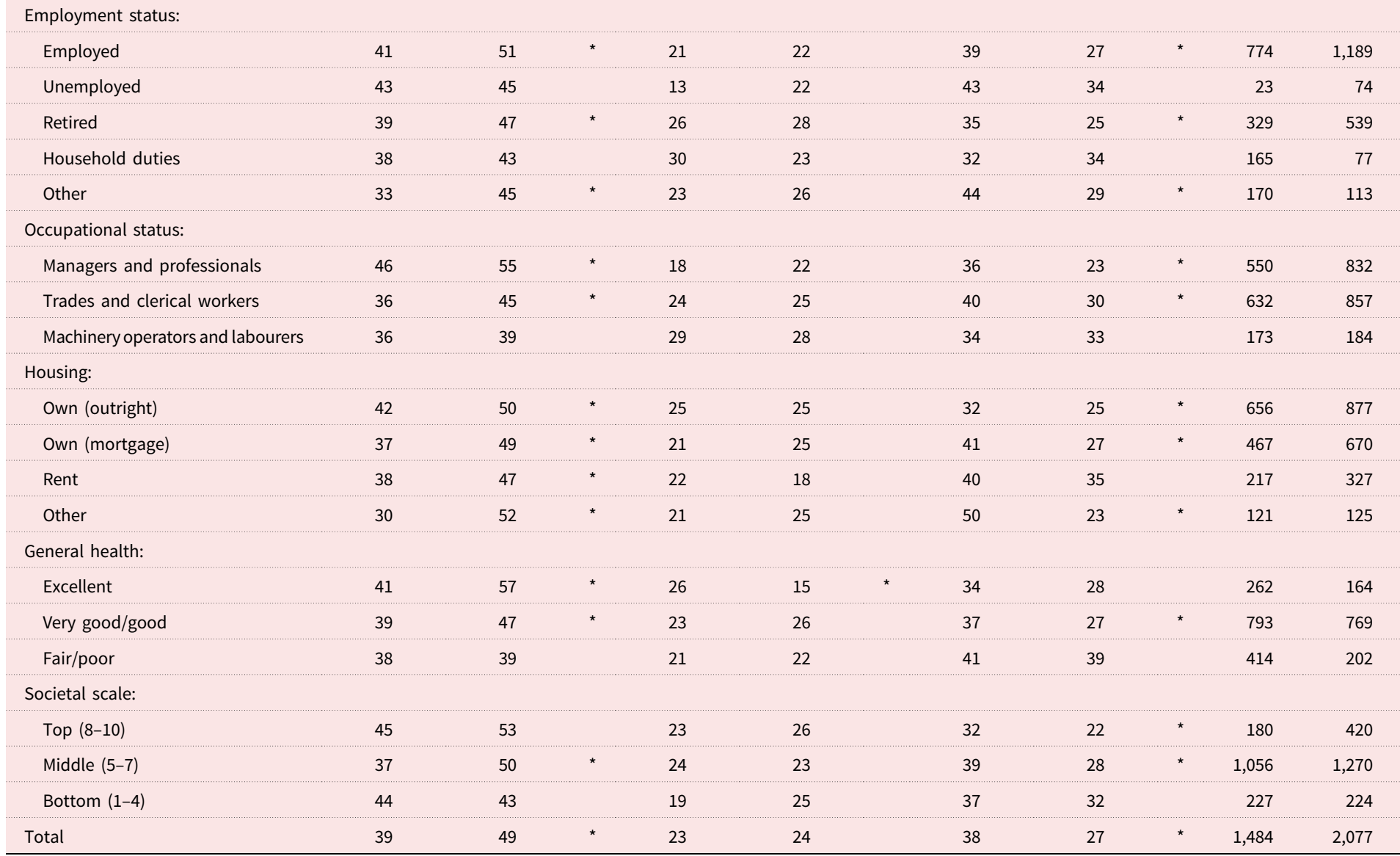

Notes: Percentages that do not add up to 100 are due to rounding error. TAFE: technical and further education. Significance level: ${ }^{*} p<0.05$. 
Table 3. Sub-group responses to the perceived life-long opportunities of baby-boomers compared to older already-retired people and change between the two time periods (2009-2010 and 2015-2017)

\begin{tabular}{|c|c|c|c|c|c|c|c|c|c|c|c|}
\hline \multirow[b]{2}{*}{ Characteristics } & \multicolumn{3}{|c|}{ Better for baby-boomers } & \multicolumn{3}{|c|}{ About the same } & \multicolumn{3}{|c|}{ Better for retired people } & \multicolumn{2}{|c|}{ Total N } \\
\hline & $\begin{array}{c}2009-10 \\
(\%)\end{array}$ & $\begin{array}{c}2015-17 \\
(\%)\end{array}$ & $p$ & $\begin{array}{c}2009-10 \\
(\%)\end{array}$ & $\begin{array}{c}2015-17 \\
(\%)\end{array}$ & $p$ & $\begin{array}{c}2009-10 \\
(\%)\end{array}$ & $\begin{array}{c}2015-17 \\
(\%)\end{array}$ & $p$ & $2009-10$ & 2015-17 \\
\hline \multicolumn{12}{|l|}{ Age cohort: } \\
\hline Young (born after 1980) & 60 & 57 & & 29 & 30 & & 10 & 13 & & 153 & 258 \\
\hline Middle (born 1965-1980) & 62 & 56 & & 28 & 29 & & 9 & 16 & * & 302 & 455 \\
\hline Baby-boomers (born 1946-1964) & 61 & 46 & * & 24 & 36 & * & 14 & 19 & * & 605 & 942 \\
\hline Older (born before 1946) & 47 & 41 & & 39 & 44 & & 13 & 15 & & 393 & 329 \\
\hline \multicolumn{12}{|l|}{ Gender: } \\
\hline Male & 59 & 49 & * & 32 & 36 & & 10 & 14 & * & 636 & 1,008 \\
\hline Female & 57 & 48 & * & 28 & 33 & & 15 & 19 & * & 827 & 1,020 \\
\hline \multicolumn{12}{|l|}{ Marital status: } \\
\hline Ever been married & 57 & 48 & * & 30 & 35 & * & 13 & 17 & * & 1,142 & 1,614 \\
\hline Never been married & 61 & 51 & * & 28 & 34 & & 11 & 15 & & 318 & 378 \\
\hline \multicolumn{12}{|l|}{ Location: } \\
\hline Metropolitan & 61 & 52 & * & 27 & 31 & & 12 & 16 & * & 906 & 1,194 \\
\hline Region & 54 & 43 & * & 33 & 41 & & 13 & 16 & & 174 & 504 \\
\hline Rural & 52 & 46 & & 33 & 36 & & 15 & 17 & & 377 & 310 \\
\hline
\end{tabular}




\begin{tabular}{|c|c|c|c|c|c|c|c|c|c|c|c|}
\hline Up to Year 12 & 49 & 41 & * & 38 & 44 & * & 13 & 15 & & 437 & 587 \\
\hline Diploma/TAFE & 57 & 48 & * & 30 & 34 & & 13 & 18 & $\star$ & 596 & 701 \\
\hline Tertiary education & 68 & 55 & * & 21 & 28 & * & 12 & 17 & * & 413 & 750 \\
\hline \multicolumn{12}{|l|}{ Employment status: } \\
\hline Employed & 63 & 53 & * & 25 & 30 & * & 12 & 17 & * & 769 & 1,182 \\
\hline Unemployed & 35 & 46 & & 30 & 35 & & 35 & 19 & & 23 & 74 \\
\hline Retired & 52 & 43 & * & 36 & 43 & & 12 & 14 & & 330 & 543 \\
\hline Household duties & 56 & 49 & & 32 & 31 & & 12 & 19 & & 163 & 77 \\
\hline Other & 52 & 39 & * & 33 & 38 & & 16 & 22 & & 172 & 112 \\
\hline \multicolumn{12}{|l|}{ Occupational status: } \\
\hline Managers and professionals & 65 & 54 & * & 23 & 30 & * & 12 & 16 & * & 552 & 829 \\
\hline Trades and clerical workers & 57 & 47 & * & 31 & 35 & & 12 & 18 & * & 626 & 857 \\
\hline $\begin{array}{l}\text { Machinery operators } \\
\text { and labourers }\end{array}$ & 51 & 33 & * & 35 & 51 & * & 14 & 16 & & 172 & 181 \\
\hline \multicolumn{12}{|l|}{ Housing: } \\
\hline Own (outright) & 57 & 47 & * & 30 & 38 & * & 13 & 14 & & 654 & 877 \\
\hline Own (mortgage) & 62 & 52 & * & 27 & 30 & & 12 & 18 & $\star$ & 464 & 665 \\
\hline Rent & 49 & 48 & & 37 & 30 & & 14 & 21 & * & 216 & 326 \\
\hline Other & 61 & 48 & * & 25 & 41 & * & 15 & 11 & & 122 & 124 \\
\hline \multicolumn{12}{|l|}{ General health: } \\
\hline Excellent & 67 & 57 & * & 24 & 27 & & 9 & 15 & & 260 & 162 \\
\hline Very good/good & 58 & 49 & * & 30 & 34 & & 12 & 17 & * & 792 & 770 \\
\hline
\end{tabular}


Table 3. (Continued.)

\begin{tabular}{|c|c|c|c|c|c|c|c|c|c|c|c|}
\hline Characteristics & \multicolumn{3}{|c|}{ Better for baby-boomers } & \multicolumn{3}{|c|}{ About the same } & \multicolumn{3}{|c|}{ Better for retired people } & \multicolumn{2}{|c|}{ Total N } \\
\hline \multicolumn{12}{|l|}{ Societal scale: } \\
\hline Top (8-10) & 72 & 53 & * & 25 & 33 & * & 4 & 14 & * & 179 & 419 \\
\hline Bottom (1-4) & 47 & 41 & & 37 & 41 & & 15 & 18 & & 226 & 221 \\
\hline Total & 58 & 49 & * & 30 & 35 & * & 13 & 17 & * & 1,480 & 2,072 \\
\hline
\end{tabular}

Notes: Percentages that do not add up to 100 are due to rounding error. TAFE: technical and further education. Significance level: * $p<0.05$. 
professionals, thought that the life-long opportunities were better for baby-boomers than for younger people or those who had already retired. A larger portion of those with self-reported excellent health and those who perceived their societal status to be the highest thought that the life-long opportunities were better for babyboomers than for already-retired people; especially when compared to those with fair/poor health and those at the bottom-end of the societal scale (see Tables 2 and 3).

In the following section, we present results of the multivariable logistic regression for baby-boomers compared to younger people, and then in relation to those who had already retired.

In the multivariable analyses for the 2009-2010 survey round, the significant variables were education, home-ownership and self-rated societal status. Respondents with high school or vocational education compared to tertiary education reported a statistically significant higher adjusted odds ratio (AOR) of perceiving better life-long opportunities for younger people compared to baby-boomers $(\mathrm{AOR}=1.8,95 \% \mathrm{CI}=1.2-2.7$ and $\mathrm{AOR}=1.7,95 \% \mathrm{CI}=1.2-2.4$, respectively $)$. Similarly, compared to home-owners (outright) those with a mortgage reported better life-long opportunities for younger people compared to baby-boomers $(\mathrm{AOR}=1.7,95 \% \mathrm{CI}=1.2-2.4$ and $\mathrm{AOR}=2.2,95 \% \mathrm{CI}=1.2-4.1$, respectively $) . \mathrm{In}$ contrast, those who rated themselves at the bottom of the societal scale perceived the opportunities to be less for young people $(\mathrm{AOR}=0.6,95 \% \mathrm{CI}=0.4-0.8)$. The findings for 2015-2017 were in a similar direction but the statistically significant covariates were gender, with females having higher odds of perceiving better lifelong opportunities for younger people ( $\mathrm{AOR}=1.5,95 \% \mathrm{CI}=1.1-2.1)$, and housing tenure, with renters having higher odds of perceiving better life-long opportunities for younger people $(\mathrm{AOR}=1.8,95 \% \mathrm{CI}=1.1-3.1)$ compared to home-owners (outright).

In the regression model on life-long opportunities for baby-boomers compared to those who had retired, the statistically significant variables for the 2009-2010 survey period included age, gender and self-rated societal status. The oldest group, i.e. those aged 65 years or older, had higher odds of considering life-long opportunities to be better for those already retired compared to baby-boomers $(\mathrm{AOR}=1.9,95 \% \mathrm{CI}=1.1-3.4)$. Females were also likely to report similar results. Those who ranked themselves at the top of the societal status showed lower odds ratios $(\mathrm{AOR}=0.3,95 \% \mathrm{CI}=0.1-0.6)$, indicating that compared to baby-boomers those who had already retired were less likely to have perceived better life-long opportunities. For the 2015-2017 survey period, similar trends were observed but the statistically significant variables included age. Younger and middle-aged respondents both had lower odds of reporting better life-long opportunities for those already retired compared to baby-boomers $(\mathrm{AOR}=0.4,95 \% \mathrm{CI}=0.2-0.8$ and $\mathrm{AOR}=0.5,95 \% \mathrm{CI}=0.3-0.9$, respectively).

\section{Fair share of government benefits for older people}

At both time periods (2009-2010 and 2015-2017), a majority of respondents thought older people were getting less than their fair share of government benefits (60 and 53\%, respectively). However, the proportion within each age cohort who 


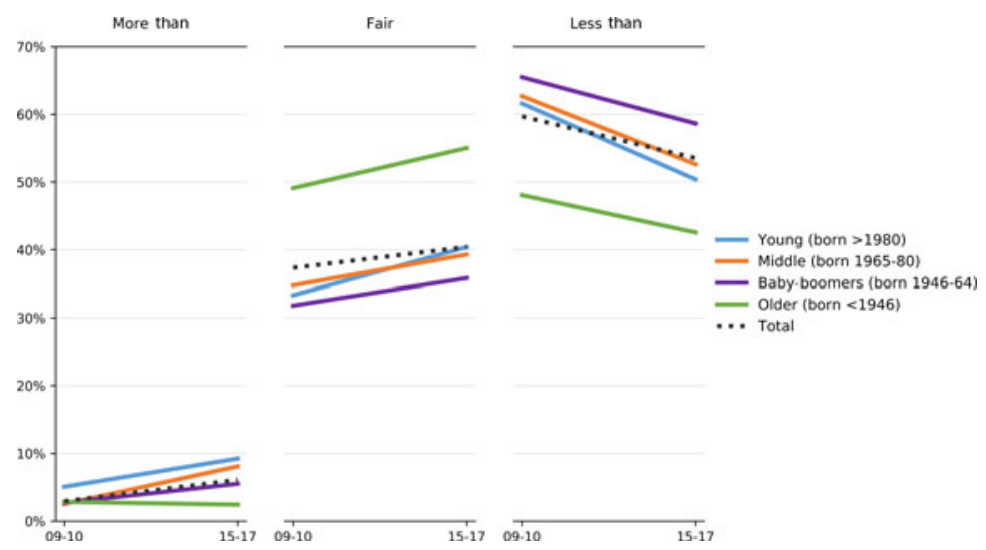

Figure 2. Older people's perceived share of government benefits.

thought older people were getting less than their fair share was lower in the 20152017 round. There was a noticeable difference between the older cohort and the other three cohorts at both time periods. Older people were the least likely cohort to think they were getting less than their fair share (48 and $43 \%$, respectively) (see Figure 2). Men, those with tertiary education, managers and professionals, and/or those who were at the top-end of the self-rated societal status were less likely than their respective counterparts to perceive that older people were getting less than their fair share of government benefits (see Table 4).

For the first survey period (2009-2010), the statistically significant variables in the multivariable analyses ('about fair share' versus 'less than their fair share') include age, education, housing tenure and self-rated societal status. Respondents who were middle-aged $(\mathrm{AOR}=1.6,95 \% \mathrm{CI}=1.0-2.7)$ or baby-boomers $(\mathrm{AOR}=$ 1.9, $95 \% \mathrm{CI}=1.3-2.8$ ) perceived older people to be getting less than their fair share of government benefits. Similarly, those with Year 12 and vocational education also showed higher odds of considering older people to be getting less than their fair share compared to those with tertiary education $(\mathrm{AOR}=2.2,95 \% \mathrm{CI}=$ 1.5-3.2 and $\mathrm{AOR}=1.7,95 \% \mathrm{CI}=1.2-2.4$, respectively). Respondents who had a mortgage (AOR 1.6, 95\% CI $=1.2-2.3$ ) were also more likely to think so compared to those who owned their house (outright). On the other hand, those who perceived themselves at the top-end of societal status were less likely than those in the middle to consider that older people were getting less than their fair share (AOR $=0.6,95 \%$ $\mathrm{CI}=0.4-0.9$ ). For the 2015-2017 survey data, similar results were observed for age (middle: $\mathrm{AOR}=2.3,95 \% \mathrm{CI}=1.2-4.5$; baby-boomers: $\mathrm{AOR}=2.1,95 \% \mathrm{CI}=1.2-$ 3.5), education (Year 12: $\mathrm{AOR}=2.2,95 \% \mathrm{CI}=1.4-3.4$; vocational education: 1.6 , $95 \% \mathrm{CI}=1.1-2.4$ ) and housing tenure (mortgage: $\mathrm{AOR}=1.5,95 \% \mathrm{CI}=1.0-2.3$ ).

\section{Intergenerational conflict}

At both time periods (2009-2010 and 2015-2017), a minority of respondents (26 and $20 \%$, respectively) perceived strong conflict and a relatively larger proportion of respondents perceived not very strong conflict between older and younger people 
Table 4. Sub-groups response to the perceived fairness of older people's level of government benefits and change between the two time periods (2009-2010 and 2015-2017)

\begin{tabular}{|c|c|c|c|c|c|c|c|c|c|c|c|}
\hline \multirow[b]{2}{*}{ Characteristics } & \multicolumn{3}{|c|}{ More than fair share } & \multicolumn{3}{|c|}{ About fair } & \multicolumn{3}{|c|}{ Less than fair share } & \multicolumn{2}{|c|}{ Total N } \\
\hline & $\begin{array}{c}2009-10 \\
(\%)\end{array}$ & $\begin{array}{c}2015-17 \\
(\%)\end{array}$ & $p$ & $\begin{array}{c}2009-10 \\
(\%)\end{array}$ & $\begin{array}{c}2015-17 \\
(\%)\end{array}$ & $p$ & $\begin{array}{c}2009-10 \\
(\%)\end{array}$ & $\begin{array}{c}2015-17 \\
(\%)\end{array}$ & $p$ & $2009-10$ & 2015-17 \\
\hline \multicolumn{12}{|l|}{ Age cohort: } \\
\hline Young (born after 1980) & 5 & 9 & & 33 & 40 & * & 62 & 50 & & 138 & 260 \\
\hline Middle (born 1965-1980) & 3 & 8 & * & 35 & 39 & * & 63 & 53 & & 276 & 458 \\
\hline Baby-boomers (born 1946-1964) & 3 & 6 & * & 32 & 36 & & 65 & 59 & * & 591 & 943 \\
\hline Older (born before 1946) & 3 & 2 & & 49 & 55 & & 48 & 43 & & 387 & 329 \\
\hline \multicolumn{12}{|l|}{ Gender: } \\
\hline Male & 5 & 8 & * & 40 & 42 & & 56 & 51 & & 613 & 1,009 \\
\hline Female & 2 & 4 & * & 36 & 40 & * & 63 & 56 & * & 790 & 1,026 \\
\hline \multicolumn{12}{|l|}{ Marital status: } \\
\hline Ever been married & 3 & 6 & * & 39 & 42 & & 58 & 53 & * & 1,106 & 1,622 \\
\hline Never been married & 4 & 9 & * & 32 & 38 & * & 64 & 53 & & 296 & 379 \\
\hline \multicolumn{12}{|l|}{ Location: } \\
\hline Metropolitan & 4 & 7 & * & 38 & 41 & * & 58 & 52 & & 854 & 1,197 \\
\hline Region & 3 & 3 & & 39 & 39 & & 58 & 58 & & 171 & 509 \\
\hline Rural & 1 & 6 & * & 34 & 44 & * & 65 & 49 & * & 372 & 310 \\
\hline \multicolumn{12}{|l|}{ Education: } \\
\hline Up to Year 12 & 2 & 2 & & 33 & 38 & & 65 & 59 & & 432 & 592 \\
\hline Diploma/TAFE & 3 & 5 & * & 35 & 37 & & 63 & 58 & & 575 & 703 \\
\hline Tertiary education & 5 & 10 & * & 45 & 46 & & 50 & 44 & & 381 & 749 \\
\hline
\end{tabular}


Table 4. (Continued.)

\begin{tabular}{|c|c|c|c|c|c|c|c|c|c|c|c|}
\hline \multirow[b]{2}{*}{ Characteristics } & \multicolumn{3}{|c|}{ More than fair share } & \multicolumn{3}{|c|}{ About fair } & \multicolumn{3}{|c|}{ Less than fair share } & \multicolumn{2}{|c|}{ Total N } \\
\hline & $\begin{array}{c}2009-10 \\
(\%)\end{array}$ & $\begin{array}{c}2015-17 \\
(\%)\end{array}$ & $p$ & $\begin{array}{c}2009-10 \\
(\%)\end{array}$ & $\begin{array}{c}2015-17 \\
(\%)\end{array}$ & $p$ & $\begin{array}{c}2009-10 \\
(\%)\end{array}$ & $\begin{array}{c}2015-17 \\
(\%)\end{array}$ & $p$ & $2009-10$ & 2015-17 \\
\hline \multicolumn{12}{|l|}{ Employment status: } \\
\hline Employed & 4 & 7 & * & 34 & 38 & * & 62 & 55 & & 729 & 1,189 \\
\hline Unemployed & 0 & 4 & & 9 & 26 & & 91 & 70 & & 22 & 73 \\
\hline Retired & 2 & 3 & & 48 & 50 & & 50 & 47 & & 327 & 542 \\
\hline Household duties & 0 & 6 & * & 39 & 35 & & 61 & 59 & & 160 & 78 \\
\hline Other & 4 & 7 & & 32 & 36 & & 64 & 57 & & 159 & 113 \\
\hline \multicolumn{12}{|l|}{ Occupational status: } \\
\hline Managers and professionals & 3 & 9 & * & 44 & 45 & & 53 & 46 & & 519 & 828 \\
\hline Trades and clerical workers & 2 & 4 & * & 32 & 38 & * & 66 & 58 & * & 607 & 859 \\
\hline Machinery operators and labourers & 4 & 3 & & 32 & 34 & & 64 & 63 & & 170 & 185 \\
\hline \multicolumn{12}{|l|}{ Housing: } \\
\hline Own (outright) & 3 & 7 & * & 45 & 48 & & 53 & 45 & * & 642 & 880 \\
\hline Own (mortgage) & 2 & 6 & * & 31 & 36 & * & 67 & 58 & & 433 & 668 \\
\hline Rent & 4 & 6 & & 30 & 31 & & 66 & 63 & & 206 & 327 \\
\hline Other & 5 & 6 & & 35 & 40 & & 59 & 53 & & 116 & 124 \\
\hline \multicolumn{12}{|l|}{ General health: } \\
\hline Excellent & 7 & 9 & & 36 & 41 & & 57 & 50 & & 244 & 159 \\
\hline Very good/good & 3 & 5 & * & 40 & 39 & & 57 & 56 & & 758 & 774 \\
\hline Fair/poor & 1 & 2 & & 34 & 35 & & 65 & 63 & & 404 & 203 \\
\hline
\end{tabular}




\begin{tabular}{|c|c|c|c|c|c|c|c|c|c|c|c|}
\hline \multicolumn{12}{|l|}{ Societal scale: } \\
\hline Top (8-10) & 8 & 11 & & 49 & 45 & & 43 & 43 & & 171 & 417 \\
\hline Middle (5-7) & 2 & 5 & * & 37 & 41 & * & 61 & 55 & * & 1,011 & 1,274 \\
\hline Bottom (1-4) & 2 & 4 & & 31 & 33 & & 67 & 63 & & 218 & 225 \\
\hline Total & 3 & 6 & * & 37 & 41 & * & 60 & 53 & * & 1,420 & 2,080 \\
\hline
\end{tabular}

Notes: Percentages that do not add up to 100 are due to rounding error. TAFE: technical and further education.

Significance level: * $p<0.05$. 


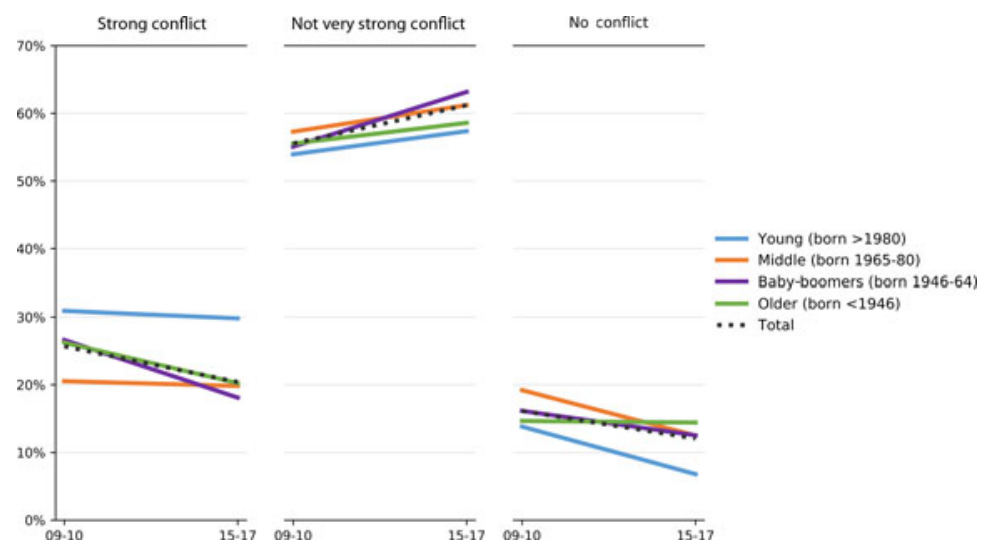

Figure 3. Perceived intergenerational conflict between older and younger people.

(55 and $61 \%$, respectively). The proportion perceiving no conflict was relatively stable (16 and $12 \%$, respectively) but these overall figures mask age and cohort effects. Younger people were the most likely to perceive strong conflict at both times (31 and 30\%, respectively), while the baby-boomers had the largest decline in perceived strong conflict (from 27 to 18\%) (see Figure 3). Respondents with selfreported fair/poor health and those who ranked themselves in the lowest societal status were more likely to perceive strong conflict than those with better health or higher societal standing (see Table 5). Statistically significant variation was seen in the difference by marital status for the two survey rounds. Respondents in the category 'never married' reported more perceived intergenerational conflict than those in the category 'ever been married' (Table 5).

In the 2009-2010 survey round, the only statistically significant variables in the multivariable analyses ('no conflict' versus 'strong conflict') were marital status, selfrated health and self-rated societal status. Respondents who were never married reported the perception of more conflict ( $\mathrm{AOR}=1.9,95 \% \mathrm{CI}=1.0-3.5)$. Those with fair/poor health reported higher odds of perceived conflict compared to those with good health $(\mathrm{AOR}=1.7,95 \% \mathrm{CI}=1.1-2.8$ ), while respondents who perceived themselves to be in the top third of societal status were less likely to perceive conflict compared to those who reported being in the mid-range (AOR $=0.5,95 \%$ $\mathrm{CI}=0.3-0.9)$. In the 2015-2017 survey data, statistically significant AOR was observed for region of residence and self-rated societal status. Respondents in rural areas were less likely than those in regional areas to perceive strong conflict $(\mathrm{AOR}=0.3,95 \% \mathrm{CI}=0.1-0.9)$. The odds of perceived conflict for those in the top third of societal scale were lower than those in the mid-range $(\mathrm{AOR}=0.4$, $95 \% \mathrm{CI}=0.2-0.8)$.

\section{Discussion}

Our AAA survey was carried out nationally at times when intergenerational budget issues had high visibility in Australia: the first round was conducted in 2009-2010 
Table 5. Sub-groups responses to the perceived level of intergenerational conflict between older and younger people and change between the two time periods (20092010 and 2015-2017)

\begin{tabular}{|c|c|c|c|c|c|c|c|c|c|c|c|}
\hline Characteristics & \multicolumn{3}{|c|}{ Strong conflict } & \multicolumn{3}{|c|}{ Not very strong conflict } & \multicolumn{3}{|c|}{ No conflict } & \multicolumn{2}{|c|}{ Total N } \\
\hline \multicolumn{12}{|l|}{ Age cohort: } \\
\hline Young (born after 1980) & 31 & 30 & & 54 & 57 & & 14 & 7 & * & 152 & 265 \\
\hline Middle (born 1965-1980) & 21 & 20 & & 57 & 61 & & 19 & 13 & * & 302 & 464 \\
\hline Older (born before 1946) & 26 & 20 & * & 56 & 59 & & 15 & 14 & & 389 & 326 \\
\hline \multicolumn{12}{|l|}{ Gender: } \\
\hline Male & 24 & 19 & * & 58 & 63 & * & 17 & 14 & & 629 & 1,010 \\
\hline Female & 27 & 22 & * & 54 & 60 & * & 16 & 10 & * & 826 & 1,041 \\
\hline \multicolumn{12}{|l|}{ Marital status: } \\
\hline Metropolitan & 24 & 20 & * & 57 & 63 & * & 16 & 12 & * & 895 & 1,215 \\
\hline Region & 31 & 25 & & 50 & 58 & & 16 & 8 & * & 174 & 507 \\
\hline Rural & 27 & 15 & * & 54 & 62 & & 16 & 15 & & 379 & 310 \\
\hline
\end{tabular}


Table 5. (Continued.)

\begin{tabular}{|c|c|c|c|c|c|c|c|c|c|c|c|}
\hline \multirow[b]{2}{*}{ Characteristics } & \multicolumn{3}{|c|}{ Strong conflict } & \multicolumn{3}{|c|}{ Not very strong conflict } & \multicolumn{3}{|c|}{ No conflict } & \multicolumn{2}{|c|}{ Total N } \\
\hline & $\begin{array}{l}2009-10 \\
(\%)\end{array}$ & $\begin{array}{l}2015-17 \\
(\%)\end{array}$ & $p$ & $\begin{array}{l}2009-10 \\
(\%)\end{array}$ & $\begin{array}{l}2015-17 \\
(\%)\end{array}$ & $p$ & $\begin{array}{l}2009-10 \\
(\%)\end{array}$ & $\begin{array}{l}2015-17 \\
(\%)\end{array}$ & $p$ & $2009-10$ & $2015-17$ \\
\hline \multicolumn{12}{|l|}{ Education: } \\
\hline Up to Year 12 & 30 & 22 & * & 51 & 56 & & 16 & 13 & & 431 & 588 \\
\hline Diploma/TAFE & 28 & 21 & * & 56 & 62 & * & 15 & 11 & & 594 & 712 \\
\hline Tertiary education & 18 & 18 & & 60 & 66 & * & 20 & 12 & * & 412 & 759 \\
\hline \multicolumn{12}{|l|}{ Employment status: } \\
\hline Employed & 23 & 20 & & 59 & 63 & * & 16 & 11 & * & 761 & 1,203 \\
\hline Unemployed & 27 & 31 & & 55 & 51 & & 9 & 9 & & 22 & 75 \\
\hline Retired & 28 & 19 & * & 55 & 61 & & 15 & 14 & & 329 & 538 \\
\hline Household duties & 23 & 27 & & 54 & 58 & & 20 & 9 & * & 167 & 78 \\
\hline Other & 34 & 22 & * & 46 & 58 & * & 17 & 11 & & 170 & 114 \\
\hline \multicolumn{12}{|l|}{ Occupational status: } \\
\hline Managers and professionals & 20 & 16 & & 60 & 66 & * & 19 & 12 & * & 547 & 836 \\
\hline Trades and clerical workers & 29 & 22 & * & 54 & 59 & & 15 & 13 & & 627 & 864 \\
\hline $\begin{array}{l}\text { Machinery operators and } \\
\text { labourers }\end{array}$ & 29 & 27 & & 55 & 54 & & 14 & 8 & & 168 & 186 \\
\hline \multicolumn{12}{|l|}{ Housing: } \\
\hline Own (outright) & 25 & 17 & * & 58 & 64 & * & 15 & 13 & & 655 & 878 \\
\hline Own (mortgage) & 23 & 19 & & 56 & 62 & * & 19 & 11 & * & 457 & 680 \\
\hline Rent & 31 & 30 & & 51 & 52 & & 15 & 11 & & 216 & 332 \\
\hline Other & 27 & 27 & & 54 & 63 & & 17 & 7 & * & 121 & 126 \\
\hline
\end{tabular}




\begin{tabular}{|c|c|c|c|c|c|c|c|c|c|c|c|}
\hline \multicolumn{12}{|l|}{ General health: } \\
\hline Excellent & 20 & 19 & & 58 & 61 & & 20 & 12 & * & 261 & 164 \\
\hline Very good/good & 23 & 19 & * & 57 & 63 & * & 16 & 12 & * & 788 & 779 \\
\hline Fair/poor & 33 & 28 & & 50 & 55 & & 13 & 7 & * & 407 & 205 \\
\hline \multicolumn{12}{|l|}{ Societal scale: } \\
\hline Top (8-10) & 19 & 15 & & 53 & 63 & * & 26 & 17 & * & 182 & 421 \\
\hline Middle (5-7) & 26 & 20 & * & 56 & 63 & * & 15 & 11 & * & 1,047 & 1,278 \\
\hline Bottom (1-4) & 31 & 33 & & 54 & 50 & & 11 & 9 & & 222 & 228 \\
\hline Total & 26 & 20 & * & 55 & 61 & * & 16 & 12 & * & 1,474 & 2,095 \\
\hline
\end{tabular}

Notes: The percentage values for the outcome variable is less than 100 due to a very small number of respondents opting for a 'don't know' option (not shown). TAFE: technical and further education.

Significance level: ${ }^{*} p<0.05$. 
after three years of policy responses to the international Credit Crisis in 2007; and then the second round in 2015-2017 during an economic slowdown. Over the last decade, the national media in Australia has had widespread coverage of ongoing policy responses to the 2007 Credit Crisis, further IGRs in 2010 and 2015, annual Budget announcements, and several election campaigns between 1998 and 2016. The Grattan Institute, an independent think-tank, has documented the economic disadvantages of recent cohorts relative to those now in later life (Daley and Wood 2014), as well as the advantaged tax and policy treatment of older people (Daley et al. 2016). Further, unfunded expenditure and ongoing tax subsidies have had major benefits for the current cohort of people aged 65 years and over, especially so for those who had accumulated substantial wealth in owning their homes and superannuation, while the ongoing debt would fall on younger people. These basic facts have been well known in specialised policy circles (e.g. Productivity Commission 2013), but were not well publicised nor understood by the general public.

Our findings on intergenerational attitudes can be interpreted in the context of a range of policy issues and recent social change including the ageing of the babyboom cohort into later life, with its substantial superannuation wealth among a minority and outright home-ownership among the majority. These advantages in the market for the baby-boom cohort earlier in their life were accentuated by policies including tax-free gains from massive house price inflation and minimally taxed superannuation accumulations. Conversely, younger people (more recent cohorts) have been entering employment and property markets that had become far less favourable for these new entrants in the Millennial cohort (Cannon and Kendig unpublished). With the growing intersection of social class and ageing, disadvantage is extending and deepening (Smith and Hetherington 2016). There has not been much policy appreciation in Australia of lifespan influences on age-based inequalities, which can be set early in life with advantage or disadvantage accumulating over the lifespan (Dannefer 2003; Kendig 2017b).

Notable increases were evident from 2009-2010 to 2015-2017 in the proportions who felt that opportunities were better for baby-boomers than for younger people; this perception was especially strong among the youngest group. Interestingly, there was a decline over time in the proportions reporting better opportunities for the baby-boomers compared to those who had already retired (Figure 1b). These findings suggest increasing sensitivity and growing public questioning of the characterisation of ageing people as a uniform group in a position of comparative need. Nonetheless, a majority continued to believe that life-long opportunities have been better for baby-boomers than for either the older or younger cohorts at the time.

A majority of respondents persisted in their view that older people were receiving less than their fair share of government benefits; interestingly, these beliefs were strongest among the baby-boomers (perhaps aware of needs in their parents' generation) and least among the older people themselves (who were basically satisfied with their lot). It would appear that the comparisons across age groups are made in the context of implicit assumptions of older people as a group being disadvantaged relative to the overall population. The findings clearly do not lend support for government propositions that benefits to older people should be cut in order to meet 
budget targets or to distribute more to younger groups. They do indicate the popular base behind parliamentary opposition to government proposals to limit expenditure on older people in order to meet budget targets (Daley and Wood 2014).

A majority of respondents perceive that intergenerational conflict is not very strong $(60 \%)$ or there is no intergenerational conflict $(15 \%)$. Moreover, over the seven years between the surveys, the proportions reporting not very strong conflict has increased. This suggests that the government's strategy of invoking intergenerational equity arguments as a rationale for cutting social expenditure has had limited impact. However, the youngest age group had the highest proportion reporting strong conflict - approximately 30 per cent for both survey times. A strengthening of these views along with cohort succession could see a backlash, particularly against government support for those older people who have significant private means and pay little tax (Daley et al. 2016). Increasing recognition of the inequalities in inherited wealth would attract greater recognition to the social divides between advantaged and disadvantaged lineages but issues of inheritance taxation have largely been beyond the scope of current political debate.

\section{Variations}

As a general pattern across the research questions, one finds a more favourable view of older people among women and among people who themselves are vulnerable in terms of their income, health or other limitations; that is, there appear to be sympathetic rather than competitive views among vulnerable people across the generations. On the strength of bonds across the generations, these observations remind us that many core orientations towards generational relations are grounded deeply in attitudes and relationships that are resistant to change. For the population as whole, attitudes change slowly in association with changes of social position, personal interests, and prevailing policy and socio-economic change as people progress through their lifespans. Future rounds of the AuSSA survey could provide opportunities to investigate stability and change of cohorts' attitudes as they grow older and experience new social and policy environments. Qualitative research could provide insights into the variations, strategies and meanings of these changes (O'Loughlin, Humpel and Kendig 2010).

We might speculate as to the reasoning behind the overall sympathetic attitudes to older people relative to other age groups. In contrast with our social difference from other vulnerable groups (e.g. race, ethnicity), we can all identify with grandparents and other older relatives in our past as well as continuing lives and also anticipate our own vulnerability in the future. In light of these fundamental social bonds, it is understandable that governments would face major struggles to foster generational or cohort conflict related to age. Ironically, there is a substantial risk that older people's capacities will be underestimated by categorical sympathy with the consequence of ageism in the workforce and other spheres of life (Sargent-Cox 2017). Such perverse outcomes would be likely to limit the contributions of older people and unnecessarily aggravate the pressures of constructively adapting to the opportunities of an ageing society (Kendig 2017b). With increasing diversity within as well as between age groups, there is every likelihood that action on ageing vulnerabilities and lifespan accumulations will need to be treated as 
different but related to social processes that are central considerations in assessing social change and consequent inequalities. In the interests of people at all ages, it is important to address the 'cultural lag' inherent when attitudes and social structures inaccurately equate age and need (Kendig 2017a; Riley, Kahn and Foner 1994). Levy (2017) conceptualises an age stereotype paradox and the need for a range of social actions that promote positive age stereotypes in line with the increasing capacities of ascendant cohorts of older people.

\section{Limitations}

Although the present paper has strengths, including using similar questions from two nationally representative survey samples thus allowing for a meaningful comparison over time, it also has limitations. The relatively low response rate from the postal questionnaire, especially for the latest round, suggests that caution should be taken in inferring population estimates from the findings. Further, as with any survey using a self-completion format, it is possible that there could be differential non-response rates from people with less education, non-English-speakers and others with limited literacy. With regards to ethnicity, the majority of respondents were Australian born or came from English-speaking countries. Therefore, we have not analysed migration differences due to the small sample size of respondents who are non-English-speakers. Finally, views on the tax benefits of home-ownership and superannuation were not explored in the baseline questions because pilot testing for the 2009-2010 survey showed they were not widely understood by the general public. Furthermore, these issues cannot be adequately explored without including a raft of questions to allow respondents to provide both quantitative and qualitative responses. The 'self-rated societal status' variable proved to be particularly useful as a summary measure for making comparative appraisals across age cohorts and social groups at different stages of life.

\section{Conclusion}

The attitudinal findings reported here show the Australian public perceives the country is at an historic turning point in that recent and future generations are expected to have relatively worse economic prospects. The Millennial cohort is thought to be relatively disadvantaged, while the baby-boom cohort is recognised for the lifelong advantages accrued, particularly during the favourable employment and housing markets of recent decades. Nonetheless, the public largely retains a sympathetic view of older people as not having a fair share of government benefits, notwithstanding available evidence of the growing numbers of tax-advantaged home-owners and superannuants at older ages. In broad terms, more sympathetic views of older people as a whole continue among women and groups who themselves are rendered vulnerable in terms of their health and social resources. Overall, the government's arguments for expenditure restraint, as presented in the IGRs, do not appear to be very consistent with the attitudes reported here. While there has been limited public concern for intergenerational inequity or conflict, public discourse is beginning to shift in line with the declining life prospects of 
younger cohorts along with the increasing housing and superannuation wealth of advantaged older people.

Acknowledgements. We would like to acknowledge Betsy Blunsdon and Adam Zammit at ACSPRI for their support in the collection and provision of the Australian Survey of Social Attitudes (AuSSA) 2015-17 data. Lisa Cannon was affiliated with CEPAR and the Australian National University until recently.

Declaration of contribution of authors. H.K. conceived of the study and wrote drafts of the introduction and discussion; R.H. with L.C. led the statistical analyses and writing of the findings; and K.O'L. contributed in establishing the study and critically reviewing the draft paper.

Funding. Our Attitudes to Ageing in Australia (AAA) study is being conducted with the support of the ARC Centre of Excellence in Population Ageing (CEPAR; CE110001029). The current paper continues on from our CEPAR working paper (Kendig et al. 2015), which reviews the methodology and examines the 2009-2010 survey data.

Conflict of interest. The authors declare no conflicts of interest.

\section{References}

Australian Consortium for Social and Political Research Inc. (2015) The Australian Survey of Social Attitudes, About AuSSA. Available online at https://www.acspri.org.au/aussa (Accessed 18 September 2017).

Australian Human Rights Commission (2015) National Prevalence Survey of Age Discrimination in the Workplace: The Prevalence, Nature and Impact of Workplace Age Discrimination Amongst the Australian Population Aged 50 Years and Older. Sydney: Australian Human Rights Commission.

Bessant JC, Emslie M and Watts R (2011) Accounting for future generations: intergenerational equity in Australia. Australian Journal of Public Administration 70, 143-155.

Binstock RH (2010) From compassionate ageism to intergenerational conflict? The Gerontologist 50, 574585.

Büttner P and Muller R (2011) Epidemiology. Melbourne: Oxford University Press.

Commonwealth of Australia (2002) Intergenerational Report 2002-03. Canberra: Australian Government.

Commonwealth of Australia (2007) Intergenerational Report 2007. Canberra: Australian Government.

Commonwealth of Australia (2010) Intergenerational Report, Australia to 2050: Future Challenges. Canberra: Australian Government.

Commonwealth of Australia (2015) 2015 Intergenerational Report Australia in 2055. Canberra: Australian Government.

Daley J, Coates B, Young W and Parsonage H (2016) Age of Entitlement: Age-based Tax Breaks. Melbourne: Grattan Institute.

Daley J and Wood D (2014) The Wealth of Generations. Melbourne: Grattan Institute.

Dannefer D (2003) Cumulative advantage/disadvantage and the life course: cross-fertilizing age and social science theory. Journals of Gerontology: Psychological Science Social Science 58B, S327-S337.

Duckett S (2015) Intergenerational report misses the point on health spending. Australasian Journal on Ageing 34, 214-216.

Higgs P and Gilleard C (2010) Generational conflict, consumption and the ageing welfare state in the United Kingdom. Ageing \& Society 30, 1439-1451.

Hudson RB (2016) Politics and policies of aging in the United States. In George LK and Ferraro KF (eds), Handbook of Aging and the Social Sciences. Eighth edition, San Diego, California: Academic Press, pp. 441-459.

Hurley K, Breheny M and Tuffin K (2017) Intergenerational inequity arguments and the implications for state-funded financial support of older people. Ageing \& Society 37, 561-580.

IBM Corp. (2016) IBM SPSS Statistics for Windows. Version 24.0, New York: IBM Corp., Armonk.

ISSP Research Group (1989) International Social Survey Programme: Social Inequality I - ISSP 1987. ZA1680 Data file version 1.0.0, GESIS Data Archive, Cologne, Germany. 
Kendig H (2010) The Intergenerational Report 2010: a double-edged sword. Australasian Journal on Ageing 29, 145-146.

Kendig H (2017a) Australian developments in ageing: issues and history. In O'Loughlin K, Browning C and Kendig H (eds), Ageing in Australia: Challenges and Opportunities. New York: Springer, pp. 13-27.

Kendig H (2017b) Directions and choices for the future. In O'Loughlin K, Browning C and Kendig H (eds), Ageing in Australia: Challenges and Opportunities. New York: Springer, pp. 263-279.

Kendig $\mathbf{H}$ and Cannon L (2016) International perspectives and global benchmarking. In Kendig H, McDonald P and Piggott J (eds), Population Ageing and Australia's Future. Canberra: ANU Press, pp. 313-317.

Kendig H, O'Loughlin K, Hussain R and Cannon L (2017) Attitudes towards intergenerational equity: preliminary Australian evidence. Australasian Journal on Ageing 36, 107-111.

Kendig H, O'Loughlin K, Hussain R, Heese K and Cannon L (2015) Attitudes to intergenerational equity: baseline findings from the Attitudes to Ageing in Australia (AAA) Study. Working paper, ARC Centre of Excellence in Population Ageing Research, Sydney.

Kendig H, Wells Y, O’Loughlin K and Heese K (2013) Australian baby boomers face retirement during the global financial crisis. Journal of Aging and Social Policy 25, 264-280.

Levy BR (2017) Age-stereotype paradox: opportunity for social change. The Gerontologist 57, S118-S126.

Kohli M and Arza C (2011) The political economy of pension reform in Europe. In Binstock R and George L (eds), Handbook of Ageing and the Social Sciences. Seventh edition, San Diego, California: Academic Press, pp. 251-264.

O'Loughlin K, Humpel N and Kendig H (2010) Impact of the global financial crisis on employed Australian baby boomers: a national survey. Australasian Journal on Ageing 29, 88-91.

Productivity Commission (2013) An ageing Australia preparing for the future. Research paper, Productivity Commission, Canberra.

Riley M, Kahn R and Foner A (1994) Age and Structural Lag: Society's Failure to Provide Meaningful Opportunities in Work, Family, and Leisure. New York: Wiley.

Sargent-Cox K (2017) Ageism: we are our own worst enemy. International Psychogeriatrics 29, 1-8.

Saunders P and Wong M (2013) Examining Australian attitudes to inequality and redistribution. Journal of Australian Political Economy 71, 51-75.

Smith W and Hetherington D (2016) The Adequacy of the Age Pension in Australia: An Assessment of Pensioner Living Standards. Sydney: Benevolent Society, the Longevity Innovation Hub and Per Capita Limited.

Walker A (1990) The economic 'burden' of ageing and the prospect of intergenerational conflict. Ageing \& Society 10, 377-396.

Woods M and Kendig H (2015) Intergenerational Report 2015: a limited political view of our future. Australasian Journal on Ageing 34, 217-219.

Cite this article: Kendig H, Hussain R, O'Loughlin K, Cannon L (2019). Australian attitudes to intergenerational equity: impacts of social and policy change. Ageing \& Society 39, 2671-2698. https://doi.org/ $10.1017 / \mathrm{S} 0144686 \mathrm{X} 18000703$. 